\title{
The Inspiration for Guizhou Province from the Domestic and Foreign Experiences of Weather Index Insurance Development
}

\begin{abstract}
Yanjun Li
School of Finance, Guizhou University of Finance and Economics, Guiyang Guizhou 550025 , China

Abstract

This paper introduces the development experience of the weather index insurance in developing countries as well as some domestic provinces and cities. It also analyzes some problems in the implementation of weather index insurance such as the difficulties in the product design, the pricing risk handling, the low purchase intention, the imperfect legal issues and so on. Finally, the paper proposes some advices for the implement of weather index insurance in Guizhou from several aspects like improving the research work, the financial support, the relevant legal issues etc.
\end{abstract}

\section{Keywords}

Weather index insurance; Product design; Financial support

\section{指数保险发展的国内外经验对贵州省的 启示}

\author{
李彦君 \\ 贵州财经大学金融学院, 贵阳 550025, 中国
}

摘要：本文介绍了本文介绍了发展中国家天气指数保险发展的经验, 以及国内部分省市开展 天气指数保险的经验, 并分析了天气指数保险实施中面临产品设计难、定价风险难于把握、 投保意愿不高、法律不完善等问题。最后论文从加大天气指数保险基础研究力度、加大财政 支持、完善相关法律等方面提出贵州实施天气指数保险的对策建议。

关键词: 天气指数保险; 产品设计; 财政支持 


\section{1. 引言}

2014 年 8 月 10 日，国务院印发 《关于加快发展现代保险服务业的若 干意见》（行业内称为 “新国十 条”），“新国十条” 明确指出 “开 展农产品目标价格指数保险试点，探 索天气指数保险等新兴产品和服 务”。天气指数保险有效减少现场查 勘和二次定损，节约了交易成本，加 快了理赔速度。同时，天气指数保险 能够有效降低道德风险, 标准合约化 的天气指数保险业有利于保险公司通 过再保险分散风险, 提高了保险公司 的抗风险能力。

在应用层面上，天气指数保险可 以分为宏观层次、中间层次和微观层 次三种不同的风险水平等级。宏观层 次是指国际组织和政府层面上的应 用、中间层次是指企业及中介层面上 的应用、微观层次是指家庭或个人层 面上的应用。天气指数保险还可与其 他金融服务捆绑（如农业贷款），通 过投保农民可以以较低利率获得贷款 或者获得更大额度的贷款金额。

国外发展中国家开展天气指数保 险取得的效果良好, 国内安徽、江 西、大连、福建等地积极开展天气指 数保险, 取得了一些成效。2014 年由 保监会财产保险监管部、农业部农村 经济研究中心、人保财险、国寿财 险、国元农险、瑞士再北京分公司开 展的课题 “天气指数保险的实践和前 景研究”表明发展天气指数保险最好 选择传统农业保险发展较为薄弱、风 险可保、风险受人为因素干预小的地 区。

贵州省作为山地经济省份，传统 的农业保险产品交易成本高，实施天 气指数保险有利于提高农户的保障和 公司经营农业保险的积极性, 故而研 究天气指数保险的国际国内经验, 为
贵州省实施天气指数保险具有一定的 理论和现实意义。

\section{2. 天气指数保险发展的国际经验}

从国际上看，美国等是发达国家 中最高开始研究并实施天气指数保险 的国家, 其中实施推广天气指数保险 最好的国家是加拿大。发展中国家则 是指数保险实践最为深入的地区，马 拉维、蒙古等发展中国家积极开展天 气指数保险产品的研究与推广。在此 主要介绍加拿大、马拉维等国家的天 气指数保险发展经验。

\section{1. 加拿大的天气指数保险}

加拿大实施的天气指数保险主要 包括气温保险、卫星卫星云图湿度保 险以及降雨不足保险等三种。

气温保险是根据农作物生长速度 及产量与温度之间的关联度设计的天 气指数保险，其保险事故的触发条件 是“区域某一时间段气温低于前 3 年 平均气温 $2^{\circ} \mathrm{C}$ 以上”。当气温达到触发 条件时, 农户可以从保险公司获得农 业保险金赔付。

卫星云图湿度保险这类天气指数 保险设计的依据是投保当年卫星云图 监测的湿度，其保险事故触发条件是 “该湿度数据低于前 3 年平均值 $80 \%$ 以 上”，保险公司就会依据保险合同的 约定对农户进行赔付。降雨不足保险 是根据降雨量数据为依据设计的天气 指数保险, 农户可对农作物生长过程 中的任意月份组合进行选择，若当年 的降水量比前 3 年平均降雨量值低 80 $\%$ ，保险公司就依据合同约定对农户 进行赔付。

加拿大天气指数保险的运作机制 可以概括为: 一是加拿大采用联邦、 省和农户 “三方缔约模式”，联邦通 过立法形式规定加拿大各省参加农业 保险的选择权, 各省有权自行立法和 
规划农业保险计划; 二是多部门合 作，各省如果决定开展农业保险，政 府部门设立农作物保险局，保险局下 设多个行政部门制定和执行相关法律 以及农业保险的开展工作。

\section{2. 墨西哥的天气指数保险}

墨西哥的天气指数保险以降雨量 为指数, 将洪涝和干旱纳为风险事 件。为了改善由于季节性自然灾害引 起的赔付支出，保险公司每年对天气 指数保险的触发水平和覆盖期间进行 评估和调整。在天气指数保险的触发 值不能真实反映天气指数保险赔偿损 失情况时，政府将启动应急资金弥补 保险公司经营天气指数保险所不能赔 偿的剩余损失。当遭遇天气灾害时， 当地政府从保险公司获取需要补偿的 农户名单, 补偿款将直接发放给农 户。天气指数保险与以前政府直接提 供援助补助金相比, 效益更高、成本 更低, 能够更加快捷地为农户提供服 务。

\section{3. 马拉维的天气指数保险}

马拉维是非洲典型的农业国家, 干旱是导致马拉维农作物大范围减产 的最主要原因。2005 年, 马拉维开始 实施天气指数保险试点方案。该试点 方案按分为两类目的：一类是以马拉 维政府为目标客户，该方案以自然灾 害发生之后的赈灾为目的; 另一类目 标客户是种植烟草的烟农, 该方案的 目的是发展天气指数保险, 提高农业 风险保障。尽管这两种目的不同，但 在天气指数保险中天气指数均为降雨 量, 风险事件为干旱, 该方案设计的 指数与风险事件是根据马拉维的国情 来定的。

马拉维的天气指数保险运作方式 为: 保险机构同小农户联合会合作， 农户承诺将生产的农作物出售给小农
户联合会时, 要求农户购买天气指数 保险。农户在生产经营过程中, 根据 需要可以向小农户联合会贷款, 小农 户联合会将从农户出售的农产品收入 中扣除贷款本息。如果发生风险事 件, 保险机构的赔款也支付给小农户 联合会, 如果农业保险赔款等于农户 的贷款金额, 农户可以获得其农产品 销售收入，小农户联合不会从其中扣 减任何费用。

\section{4. 蒙古天气指数保险}

在蒙古国经济中, 畜牧业占有重 要的地位, 干旱和冬季严寒严重威胁 牲畜业的发展, 造成经济减退、失业 增加的不良影响。2000-2002 年的严寒 对蒙古非农业部门造成了重大冲击, 导致蒙古人口失业率暴增。如在 2005 年, 蒙古政府与世界银行签订协议, 同意世界银行在蒙古试点以县域为主 的牲畜死亡率指数保险项目。

蒙古牲天气指数保险设计的特点 体现为公私合作的风险管理以及风险 的分层管理、分层融资结构、建立牲 畜保险赔偿资金池三点。这种设计可 以在我国北方农业保险中应用。

\section{3. 天气指数保险发展的国内概况}

我国首个天气指数农业保险是由 安信农业保险股份有限公司设计实施 的。安信农业保险股份有限公司于 2007 年 4 月推出了西甜瓜梅雨强度指 数保险。国元农业保险股份公司与联 合国世界粮食计划署等机构合作开展 了安徽省 “农村脆弱地区天气指数农 业保险” 合作项目。随后, 江西、山 东、福建、黑龙江、北京等地也逐渐 开始积极研发和试点天气指数保险。

2009 年, 安徽省 “农村脆弱地区 天气指数农业保险” 合作项目开发完 成了两项天气指数保险试点项目产品 设计：一种是水稻内涝天气指数保险 
产品, 该种产品的保险责任是洪涝灾 害, 试点地区是安徽省怀远县; 另一 种水稻干旱天气指数保险产品, 该种 产品的责任是干旱灾害, 试点地区是 安徽省长丰县。截至 2014 年 5 月, 全 国预备实施和正在实施的天气指数保 险品种有 9 种, 区域集中在中东部地 区, 保险保障范围涵盖了水产养殖业 和种植业。

具体而言：安信农业保险公司于 2007 年在上海地区试点推广西甜瓜梅 雨强度指数保险, 承保梅雨风险; 国 元农业保险公司于 2010 年在安徽省宿 州市、长丰县试点推广花生种植天气 指数保险, 承保干旱与洪涝灾害; 国 元农业保险公司于 2011 年在安徽南 陵、无为等县试点水稻高温热害天气 指数保险, 承保高温旱灾; 人保财险 于 2011 年在江西省南丰县试点蜜桔树 气象指数保险, 承保秋季低温灾害;

国寿财险于 2011 年在福建省长汀县试 点烟叶冻灾和水灾指数保险, 承保冻 灾和水灾; 人保财险 2012 年在山东大 连、长岛、荣成等养殖海域试点了海 珍品风力指数保险, 承保风灾; 阳光 农业保险公司于 2014 年在鸡西、黑河 等地区试点推广大豆、玉米种植保 险, 承保干旱与内涝灾害; 人保财险 于 2014 年在北京等地试点蜂业保险, 承保干旱与阴天等气象灾害; 另外, 还有人保财险还在开发论证橡胶风灾 指数保险。国内现有的天气指数保险 试点经验为国内其他尚未开展天气指 数保险的省份提供经验。

\section{4. 国内外天气指数保险实施经验对贵 州实施天气指数保险的启示}

发达国家中的加拿大天气指数保 险实施取得了良好的效果, 故而加拿 大天气指数保险的做法值得我们借 鉴。国内的部分地区的做法也值得我 们学习。
贵州省长期以来容易遭受干旱、 冰冻、洪涝、病虫害等自然灾害, 发 生频率高、分布地区广泛, 严重制约 贵州省农业经济的发展。同时, 贵州 是山地经济, 交通不便, 传统农业保 险产品面临理赔查勘定损困难等问 题。天气指数保险作为一种新的农业 巨灾风险管理方式, 能够为农业生产 和农民生活提供更充足的保障, 降低 经营成本。为了促进贵州省天气指数 保险的发展, 提出如下建议:

\section{1. 开展天气指数保险基础研究}

天气指数保险是对传统政策性农 业保险的创新。天气指数保险产品设 计、定价等精算技术复杂, 需要专门 研究。建议政府、企业与高校等科研 机构合作，开展贵州省天气指数保险 理论研究, 开发设计适合贵州省省情 的天气指数保险产品。

\section{2. 政府积极推动天气指数保险工作, 在合适的地区进行试点}

根据国内开展天气指数保险的经 验, 天气指数保险的试点一般选择传 统政策性农业保险尚未实施或薄弱的 地区。贵州省相较国内其他省份而 言, 农业保险不发达, 试点推广天气 指数保险正当其时。政府和保险公司 根据目前农业保险开展情况, 可以选 择贵州省尚未开展农业保险的若干地 区开发试点干旱、气温等天气指数保 险。

\section{3. 积极寻求国际组织支持的试点项目}

天气指数保险发展的国际经验表 明, 先行试点、逐步推广是其成功的 路径。国内安徽省提供了很好的经验 借鉴。建议政府、保险机构应该积极 主动与世界银行、亚洲开发银行、联 合国世界粮食计划署等国际机构取得 
联系, 合作开展贵州省天气指数保险 开发试点项目。

\section{4. 完善贵州省的农业保险制度体系}

贵州政府部门、保险公司应扮演 一定的参与和推动角色, 将天气指数 保险纳入到政策支持范围内, 与现有 的政策性农业保险协调发展，最终构 建一个多渠道、多机构、多形式、多 服务、多产品的农业保险制度体系。

\section{5. 完善法律监管}

从加拿大的发展经验来看, 其最 大的特点是通过立法形式确定各省份 参加农业保险的选择权, 如果各省份 参加农业保险，则各省份可以指定相 关法律，规定政府的财政补贴方式及 金额，以及对保险机构经营农业保险 的行为进行监管。针对天气指数保险 发展过程中的一系列违法违规行为, 应当通过建立严格的法律和监管体系 对其进行约束和惩罚。

\section{参考文献}

[1] 姚庆海, 气象灾害与天气指数保险 研究 $[\mathrm{J}]$. 上海保险. 1：7-11, 2015.

[2] 夕月，气象指数保险为 “不测风云 买单”, 绿色中国 $B$ 版, 3: 64$66,2015$.

[3]于宁宁, 农业气象指数保险研究, 山东农业大学, 2011.

[4]度国柱，论中国及世界农业保险产 品创新和服务创新趋势及其约束, 中国保险，2：14-21，2014.

[5]高娇，指数保险发展：基于印度、 蒙古、秘鲁和马拉维的案例分析, 农村经济与科技，7：91-94， 2012.
[6]范红丽, 刘玮, 天气指数保险在发 展中国家的应用及启示, 上海保 险, 1: 2015.

[7] 吴珊, 天气指数保险及其定价研 究, 西南财经大学, 2014. 